\title{
Podridão de raízes causada por Pythium aphanidermatum, em cultivares de alface produzidas em sistema hidropônico
}

\author{
Zayame Vegette Pinto $^{1 *}$, Matheus Aparecido Pereira Cipriano ${ }^{2 * *}$, José Abrahão Haddad Galvão ${ }^{1,3}$, Wagner Bettiol ${ }^{3 *}$, \\ Flávia Rodrigues Alves Patrício ${ }^{4}$ e Amaury da Silva dos Santos 5 .
}

${ }^{1}$ Faculdade de Ciências Agronômicas, FCA/UNESP, Rod. Alcides Soares Km 3, 18610-307, Botucatu, SP, Brasil; ${ }^{2}$ Instituto Agronômico CP 270, 13012-970, Campinas, SP; ${ }^{3}$ Embrapa Meio Ambiente, CP 69, 13820-000, Jaguariúna, SP, ${ }^{4}$ Instituto Biológico de São Paulo CP 70, 13001-970, Campinas, SP; ${ }^{5}$ Embrapa Tabuleiros Costeiros, CP 44, 49025-040, *Bolsista CNPq, **bolsista CAPES.

Autor para correspondência: Wagner Bettiol (bettiol@cnpma.embrapa.br)

Data de chegada: 20/10/2010. Aceito para publicação em: 10/10/2011.

\section{RESUMO}

Pinto, Z.V.; Cipriano, M.A.P.; Galvão, J.A.H.; Bettiol, W.; Patrício, F.R.A.; Santos, A.S. Podridão de raízes causada por Pythium aphanidermatum, em cultivares de alface produzidas em sistema hidropônico. Summa Phytopathologica, v.37, n.4, p.180-186, 2011.

A podridão de raízes, causada por Pythium aphanidermatum e outras espécies de Pythium, é a principal doença da alface cultivada em sistemas hidropônicos no Brasil. O presente trabalho teve como objetivo avaliar quatro cultivares comerciais de alface em relação à sensibilidade a podridão de raízes, causada por P. aphanidermatum. Os estudos foram realizados em placas de Petri contendo ágar-água com plântulas de alface das cultivares crespa (Vera e Verônica) e lisa (Regina e Elisa), infestadas ou não com o patógeno. Com as mesmas cultivares foram realizados quatro experimentos em sistemas hidropônicos (Nutrient Film Technique), sendo dois em estufa coberta com plástico e sombrite e dois em estufa coberta apenas com plástico. As plântulas, infectadas ou não com $P$. aphanidermatum, foram transplantadas para os sistemas infestados ou não. Foi avaliada a severidade da doença e o desenvolvimento das plantas. Todas as cultivares foram suscetíveis à podridão de raízes nos experimentos realizados in vitro e in vivo. A presença do sombrite não reduziu a podridão de raízes em cultivares de alface produzidas no sistema hidropônico. A cultivar Regina apresentou maior massa de matéria seca da parte aérea e das raízes, na presença ou ausência do patógeno, sendo a mais indicada para o cultivo hidropônico na época mais quente do ano.

Palavras-chave adicionais: Lactuca sativa, Pythium, podridão de raízes, sistema hidropônico.

\section{ABSTRACT}

Pinto, Z.V.; Cipriano, M.A.P.; Galvão, J.A.H.; Bettiol, W.; Patrício, F.R.A.; Santos, A.S. Root rot caused by Pythium aphanidermatum of lettuce cultivars produced in a hydroponic system. Summa Phytopathologica, v.37, n.4, p.180-186, 2011.

Lettuce root rot caused by Pythium aphanidermatum and other Pythium species is the main disease in hydroponic systems in Brazil. The present work aimed to evaluate the behavior of four commercial lettuce cultivars as to their sensitivity to root rot caused by $P$. aphanidermatum in hydroponic systems. Experiments were conducted in Petri dishes containing water-agar medium and seedlings of the crisp head lettuce cultivars (Vera and Verônica) and leafy lettuce cultivars (Regina and Elisa), infested or not with the pathogen. With the same cultivars, four other experiments were carried out in hydroponic systems (Nutrient Film Technique), two in a shaded greenhouse and the other two in a conventional greenhouse. Seedlings infected or not with $P$. aphanidermatum were transplanted to hydroponic systems infested or not with the pathogen. The disease severity and the plant development were evaluated. All cultivars were susceptible to root rot in both in vitro and in vivo experiments. The shading did not reduce root rot in the lettuce cultivars in hydroponic system. The cultivar Regina showed higher shoot and root dry mass in the presence or absence of the pathogen, constituting thus the most suitable cultivar for hydroponic systems during the hottest period of the year.

Keywords: Lactuca sativa, Pythium, root rot, hydroponic system.

A alface (Lactuca sativa L.) é a principal hortaliça produzida em sistemas hidropônicos no Brasil. Isso ocorre devido às vantagens oferecidas por esse sistema em relação ao cultivo convencional, como o aumento da qualidade e homogeneidade das cabeças de alface e maior facilidade na sua higienização $(10,14)$. Outra vantagem para os agricultores é a ocupação de uma menor área produtiva e a possibilidade do cultivo durante o ano todo, principalmente em épocas chuvosas, em que o preço da alface é mais elevado (22). A Técnica do Fluxo Laminar, também conhecida como Nutrient Film Technique (NFT), no qual as plantas permanecem com as raízes submersas em solução nutritiva, que circula em fluxo contínuo dentro de canaletas, é o sistema mais utilizado no Brasil (22).

Além das vantagens descritas, uma das razões para o incremento na utilização de sistemas hidropônicos no Brasil é a de que, de maneira geral, este cultivo implica em menores prejuízos decorrentes do ataque de patógenos veiculados pelo solo. Entretanto, em sistemas hidropônicos, podridões de raízes causadas por Pythium spp. podem causar grandes prejuízos, especialmente no verão (26). Pythium é favorecido devido à sua boa adaptabilidade a ambientes aquáticos e por se disseminar por meio de zoósporos biflagelados, que circulam 
junto com a solução nutritiva, atingindo todo o sistema hidropônico $(3,16,26)$. Também contribui para o aumento dos danos o fato de que esse sistema apresenta menor diversidade biológica que o solo (26). Diversas espécies de Pythium foram detectadas em sistemas hidropônicos como $P$. ultimum, $P$. aphanidermatum, $P$. helicoides, $P$. debaryanum, $P$. dissotocum, $P$. intermedium, $P$. irregulare, $P$. myriotylum, $P$. sylvaticum e Pythium dos grupos $\mathrm{F}$ e $\mathrm{T}$ em alface $\mathrm{e}$ outras culturas $(16,25,26,27)$. $P$. aphanidermatum encontra-se entre as espécies mais prejudiciais em alface cultivada em sistemas hidropônicos (5) e é uma das espécies que se dissemina mais rapidamente no sistema (3).

As temperaturas favoráveis para a produção de alface de boa qualidade estão entre 15 e $24{ }^{\circ} \mathrm{C}$ (8). Entretanto, Mattos et al. (11) verificaram para as condições brasileiras temperaturas médias de 22 a $30{ }^{\circ} \mathrm{C}$ no ambiente, e de 23 a $31,2{ }^{\circ} \mathrm{C}$ no interior das canaletas de sistemas hidropônicos no período do verão. Estas temperaturas, além de prejudicar a produção, ainda favorecem a infecção das plantas por espécies de Pythium (26) que, nas épocas mais quentes do ano, exibem sintomas característicos de podridão de raízes (26). Uma das alternativas para reduzir a temperatura do ambiente protegido é a utilização de telas de sombreamento (19).

As cultivares de alface mais comercializadas no Brasil, do tipo crespa, têm boa adaptabilidade aos sistemas hidropônicos $(6,23)$. Em cultivos comerciais, produtores de alface hidropônica relatam que as cultivares do tipo crespa são mais suscetíveis à podridão de raízes causada por Pythium, especialmente no verão. Patekosky \& PiresZotarelli (18) observaram que plântulas de alface das cultivares Vera (crespa) e Elisa (lisa) foram suscetíveis à podridão de raízes causada por $P$. aphanidermatum em experimentos conduzidos in vitro. Com a crescente atratividade dos sistemas hidropônicos para os produtores de alface, programas de melhoramento genético visando ao desenvolvimento de cultivares exclusivamente para uso nesses sistemas deverão se expandir (15), sendo a detecção de fontes de resistência de grande importância para esses programas. Adicionalmente, cultivares comerciais que apresentem maior resistência ou tolerância ao patógeno nessa condição pode facilitar o manejo da podridão radicular com outros métodos de controle.

O presente trabalho teve como objetivo avaliar a reação de quatro cultivares comerciais de alface (tipos lisa e crespa) em relação à podridão de raízes, causada por $P$. aphanidermatum.

\section{MATERIAL E MÉTODOS}

A reação de quatro cultivares de alface, sendo duas crespas e duas lisas, a $P$. aphanidermatum foi avaliada em dois experimentos conduzidos in vitro e quatro experimentos in vivo.

$\mathrm{O}$ isolado de $P$. aphanidermatum utilizado nos experimentos foi obtido de plântulas de pepino com sintomas de tombamento e pertence à coleção de culturas do Laboratório de Fitopatologia do Instituto Biológico. As sementes de alface foram obtidas no comércio local e encontravam-se tratadas com $0,2 \%$ do fungicida Thiran. Antes de serem colocadas para germinar as sementes foram lavadas em água corrente por uma hora, para a remoção do fungicida. Cada experimento foi realizado com diferentes lotes de sementes.

No primeiro experimento realizado in vitro foram testadas as cultivares Vera (crespa) e Elisa (lisa) e no segundo as cultivares Verônica e Vera (crespas) e Elisa e Regina (lisas). O primeiro experimento foi conduzido em esquema fatorial 2 × 2 , sendo o fator 1 patógeno (com e sem P. aphanidermatum) e o fator 2 cultivares (Vera e Elisa). O segundo experimento foi conduzido em esquema fatorial $2 \times 4$, sendo o fator 1 patógeno (com e sem $P$. aphanidermatum) e o fator 2 cultivares (Vera, Verônica, Regina e Elisa). Ambos os experimentos foram realizados em delineamento inteiramente casualizado, com cinco repetições, sendo cada repetição representada por uma placa de Petri, contendo 10 plântulas de alface. Após a análise de variância as médias foram comparadas pelo teste de Tukey a $5 \%$ de probabilidade.

As placas de Petri utilizadas nos experimentos continham meio de cultura ágar-água e sementes pré-germinadas de alface, segundo metodologia adaptada de Yañez (29). Para promover a pré-germinação, foram colocadas 25 sementes em placas de Petri sobre papel de filtro umedecido (duas folhas por placa). As placas permaneceram por $24 \mathrm{~h}$ em ambiente de laboratório, até a emissão das radículas. Em seguida, em cada placa, foram colocadas, equidistantes, 10 sementes de alface pré-geminadas próximas à borda da placa. No centro foi disposto um disco com micélio do patógeno, obtido de placas com colônias crescidas por $48 \mathrm{~h}$ em meio batata dextrose agar (BDA). Durante os experimentos as placas foram mantidas a $28{ }^{\circ} \mathrm{C} \pm 2{ }^{\circ} \mathrm{C}$ com fotoperíodo de $12 \mathrm{~h}$. Esta temperatura foi escolhida em experimentos prévios porque permitia o crescimento da alface e a manifestação dos sintomas do patógeno, sendo favorável ao desenvolvimento de P. aphanidermatum. O comprimento da radícula e a porcentagem de sobrevivência das plântulas, após a transferência das plântulas para as placas, foram avaliados após cinco dias no primeiro experimento e sete no segundo. As plântulas foram deixadas por mais tempo no segundo experimento, para que os sintomas se manifestassem em todas as cultivares.

In vivo foram instalados quatro experimentos distintos, conduzidos em sistemas hidropônicos mantidos em dois ambientes, o primeiro em uma casa-de-vegetação coberta com filme plástico transparente (150 $\mu \mathrm{m}$ de espessura com aditivo estabilizador de luz ultra-violeta), tendo abaixo do plástico um sombrite que permitia que $70 \%$ da radiação solar penetrasse no ambiente e o segundo em uma casa-de-vegetação convencional, coberta apenas com o filme plástico transparente. Os dois primeiros experimentos foram realizados simultaneamente, de fevereiro a março de 2006, sendo o primeiro no ambiente com sombrite e o segundo no sem sombrite. Os dois últimos experimentos foram realizados de março a abril de 2006, nos mesmos sistemas, sendo o terceiro com sombrite e o quarto sem sombrite. Nos quatro experimentos foram utilizadas as cultivares Verônica, Vera, Elisa e Regina. Para tanto, as sementes de alface foram semeadas em espuma fenólica (Green-up - Atlanta ${ }^{\circledR}$ ) e, após cinco dias, as plântulas foram transferidas para o berçário, estrutura utilizada nos sistemas hidropônicos para a produção de mudas. $\mathrm{O}$ berçário foi constituído por 10 canaletas de $6,4 \mathrm{~m}$ de comprimento, $0,03 \mathrm{~m}$ de diâmetro e 0,05 $m$ de distância entre as canaletas, com $30 \%$ de declividade. Um tanque com solução nutritiva (Qualifértil ${ }^{\circledR}$, com $0,7 \mathrm{mS}$ de condutividade elétrica) abastecia as canaletas do berçário durante a produção de mudas de todos os experimentos. Visando evitar a sua contaminação com o patógeno, o berçário foi totalmente isolado das demais estruturas hidropônicas e as mudas não foram inoculadas nesta fase.

As mudas, com 10 a 15 dias de idade, com três folhas verdadeiras e expandidas, foram retiradas do berçário e mergulhadas por 30 minutos em bandejas contendo uma suspensão de zoósporos de $P$. aphanidermatum $\left(10^{4}\right.$ zoósporos $\left./ \mathrm{mL}\right)$, produzidos conforme Rahimian \& Banihashemi (21). As testemunhas (sem inóculo do patógeno) foram submetidas a procedimento semelhante, mas apenas com água destilada.

As mudas inoculadas e não inoculadas foram transferidas para os sistemas hidropônicos definitivos, nas casas-de-vegetação com e sem sombrite. Os tanques dos tratamentos inoculados (contendo 50 litros de solução nutritiva) receberam ainda $200 \mathrm{~mL}$ da suspensão de zoósporos. 
Ambos os sistemas tinham 12 canaletas de $5,9 \mathrm{~m}$ de comprimento e $0,10 \mathrm{~m}$ de diâmetro, contendo 24 furos cada, acopladas, separadamente, a um tanque de $50 \mathrm{~L}$ contendo a solução nutritiva que recirculava com auxílio de uma bomba. Esses tanques eram individualizados (um tanque por tratamento) para que não houvesse mistura entre os tratamentos com e sem o patógeno. Foi utilizada a solução nutritiva Qualifértil ${ }^{\circledR}$, sendo a condutividade monitorada e ajustada para 1,5 mS diariamente por meio da adição de água sem cloro e/ou solução nutritiva aos tanques. Cada canaleta continha três parcelas, com oito plantas de cada cultivar em cada parcela. Durante a condução dos experimentos a temperatura máxima e mínima de cada ambiente foi medida nos dias úteis. No momento da colheita a severidade da podridão de raízes foi avaliada por meio da escala de notas de 0-10, desenvolvida por Khan et al. (7), sendo as notas $0=0 \%, 1=1-10 \%$, $2=11-20 \%, 3=21-30 \%, 4=31-40 \%, 5=41-50 \%, 6=51-60 \%, 7=$ $61-70 \%, 8=81-90 \%$ e $10=91-100 \%$ de severidade da podridão de raízes. Também se avaliou a massa da matéria seca da parte aérea e das raízes, aos 30 dias após a transferência das mudas para o sistema definitivo, para o primeiro e segundo experimentos, e 45 dias, para o terceiro e quarto experimentos.

Para a confirmação da presença do patógeno no sistema, uma parte das raízes foi transferida para placas de Petri com meio de cultura V8 e essas incubadas a $24{ }^{\circ} \mathrm{C}$ para posterior observação do patógeno em microscópio óptico. Os experimentos foram realizados em esquema fatorial $4 \times 2$, sendo quatro cultivares (Elisa, Regina, Verônica e Vera) e com e sem P. aphanidermatum, em delineamento de blocos ao acaso com três repetições, sendo cada repetição representada por oito plantas.

\section{RESULTADOS E DISCUSSÃO}

No primeiro experimento realizado in vitro, as cultivares não diferiram quanto ao comprimento de plântulas e não apresentaram redução na sobrevivência, quando inoculadas com P. aphanidermatum, e também não houve interação entre os fatores. Entretanto, as plântulas inoculadas apresentaram menor comprimento que as não inoculadas (Tabela 1). No segundo experimento também não houve interação entre os fatores. Quando as plântulas foram inoculadas com o patógeno, a sobrevivência para a cultivar Elisa foi de $100 \%$, diferindo significativamente da cultivar Vera, com $91 \%$ de sobrevivência, mas não diferindo das demais cultivares. As plântulas inoculadas com $P$. aphanidermatum apresentaram comprimento médio de $2,77 \mathrm{~cm}$, enquanto as não inoculadas tiveram comprimento de 4,01 cm (Tabela 1). Essa redução no desenvolvimento das plântulas inoculadas demonstra o potencial patogênico de $P$. aphanidermatum $(5,13)$. A temperatura de $28{ }^{\circ} \mathrm{C}$ utilizada nos experimentos, próxima à de $27{ }^{\circ} \mathrm{C}$ adotada por Gold \& Staghellini (5) para o mesmo patógeno, deve ter favorecido o desenvolvimento de $P$. aphanidermatum. Estudos em condições controladas mostraram que $P$. aphanidermatum causa mais danos a plantas de beterraba em temperaturas de 25 até $35^{\circ} \mathrm{C}$ (20). No Brasil, Teixeira et al. (27) observaram maiores danos a $30^{\circ} \mathrm{C}$ que a 20 ${ }^{\circ} \mathrm{C}$ em plântulas de alface inoculadas com 12 isolados (obtidos em sistemas hidropônicos) de espécies de Pythium. Patekosky \& PiresZotarelli (18) observaram maiores danos a plântulas de alface em experimento conduzido a $31{ }^{\circ} \mathrm{C}$ que em outro realizado a $20{ }^{\circ} \mathrm{C}$, e Baptista et al. (2) constataram maiores danos a sistemas radiculares de alface causados por $P$. dissotocum na temperatura de $27{ }^{\circ} \mathrm{C}$, que também foi a mais favorável ao crescimento do patógeno em meio de cultura. Além disso, $P$. aphanidermatum exibe o ótimo de germinação de oósporos na temperatura de $30{ }^{\circ} \mathrm{C}$ (1). A temperatura de $28{ }^{\circ} \mathrm{C}$ também pode ter afetado negativamente o crescimento das plântulas de alface, especialmente considerando que as temperaturas ideais de crescimento dessa hortaliça se situam entre 15 e $24{ }^{\circ} \mathrm{C}$ (8), contudo simula as temperaturas encontradas no verão no interior de canaletas de sistema hidropônico localizado em estufa na região de Campinas, SP, quando foram alcançadas médias de 28,9 a 31,2 durante o dia e de 23,1 a $24,0^{\circ} \mathrm{C}$ à noite (11).

Nos experimentos realizados in vitro, todas as cultivares foram suscetíveis a $P$. aphanidermatum, semelhantemente ao observado por Baptista et al. (2) quando inoculou $P$. dissotocum nas cultivares dos tipos mimosa (Mimosa), crespa (Vera), americana (Tainá) e lisa (Elisa) e Patekosky \& Pires-Zotarelli (17) com P. aphanidermatum nas mesmas cultivares. Nesse último estudo, entretanto, a cultivar Mimosa apresentou certa resistência ao patógeno, com maior comprimento de plântulas que as demais, que não diferiram entre si.

No primeiro e segundo experimentos conduzidos in vivo houve interação entre os fatores para a severidade da podridão de raízes (Tabela 2), mas não para a massa seca da parte aérea e do sistema radicular (Tabela 3 ). Todas as cultivares apresentaram elevada severidade da podridão de raízes nos tratamentos inoculados com o patógeno. Acultivar Vera teve a maior severidade da doença no primeiro experimento, enquanto no segundo a cultivar Verônica foi a mais afetada, com nota 6,83 , mas não diferiu significativamente das cultivares Vera e Elisa, com notas 6,46 e 6,67, respectivamente (Tabela 2).

No primeiro experimento não houve interação entre os fatores para a massa da matéria seca da parte aérea e do sistema radicular. As cultivares Elisa e Regina apresentaram maior massa da matéria seca da parte aérea $(7,31$ e 7,17 g, respectivamente), diferindo significativamente das cultivares Verônica e Vera (6,45 e 6,12 g, respectivamente) (Tabela 3 ). Com relação ao sistema radicular, a cultivar Regina apresentou

Tabela 1. Comprimento de plântulas e sobrevivência de quatro cultivares de alface, na presença e ausência de Pythium aphanidermatum.

Experimento 1

\begin{tabular}{lcc} 
Fatores & Comprimento das plântulas & Sobrevivência \\
\hline Cultivares & $(\mathrm{cm})$ & $(\%)$ \\
\hline Vera (crespa) & $4,90 \mathrm{a}$ & 100,00 \\
Elisa (lisa) & $5,03 \mathrm{a}$ & 100,00 \\
\hline P. aphanidermatum & & \\
\hline Com & $4,55 \mathrm{~b}$ & 100,00 \\
Sem & $5,39 \mathrm{a}$ & 100,00 \\
CV $(\%)$ & 11,7 & - \\
\hline
\end{tabular}

Experimento 2

Fatores Comprimento das plântulas Sobrevivência

\begin{tabular}{lcc}
\hline Cultivares & $(\mathrm{cm})$ & $(\%)$ \\
\hline Verônica (crespa) & $3,54 \mathrm{~b}^{1}$ & $97,0 \mathrm{ab}$ \\
Vera (crespa) & $2,64 \mathrm{~b}$ & $91,0 \mathrm{~b}$ \\
Elisa (lisa) & $4,83 \mathrm{a}$ & $100,0 \mathrm{a}$ \\
Regina (lisa) & $2,54 \mathrm{~b}$ & $96,0 \mathrm{ab}$ \\
\hline P. aphanidermatum & & $82,0 \mathrm{~b}$ \\
\hline Com & $2,77 \mathrm{~b}$ & $100,0 \mathrm{a}$ \\
Sem & $4,01 \mathrm{a}$ & 6,56 \\
\hline CV $(\%)$ & 25,56 & s.
\end{tabular}

${ }^{1}$ Médias seguidas por letras distintas diferem entre si ao nível de significância de 5\% Tukey. 
Tabela 2. Severidade da podridão de raízes de quatro e cultivares de alface, em sistema hidropônico, na presença e ausência de Pythium aphanidermathum do primeiro e segundo experimentos (Fevereiro a Março de 2006).

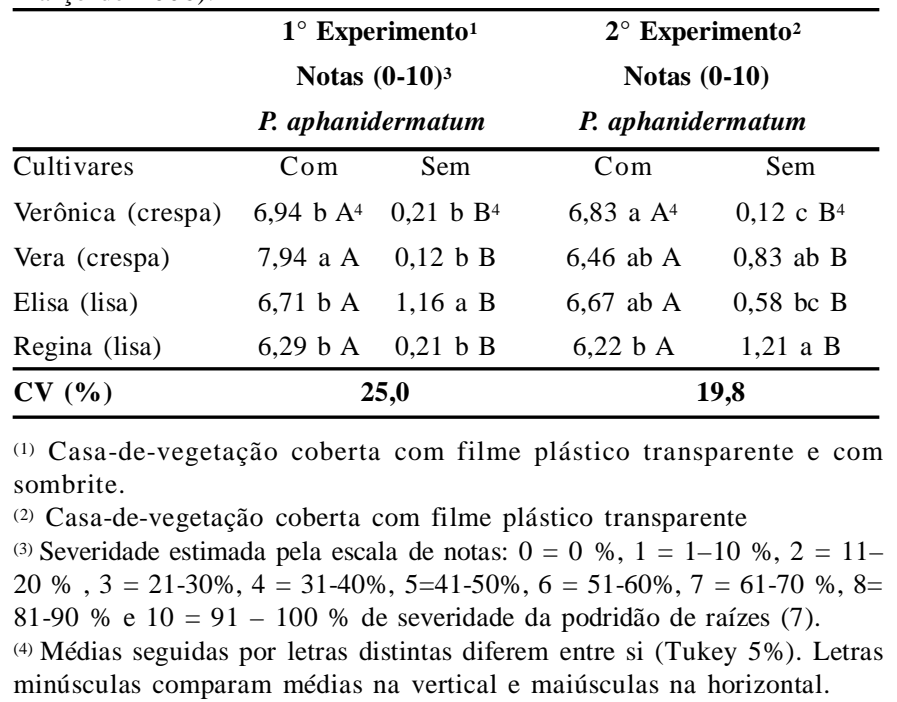

maior massa de matéria seca $(0,93 \mathrm{~g})$ que as demais cultivares. A cultivar Verônica apresentou a menor massa seca das raízes $(0,66 \mathrm{~g}) \mathrm{e}$ não diferiu da cultivar Vera $(0,68 \mathrm{~g})$. No segundo experimento não houve interação para a massa da matéria seca da parte aérea, mas houve para a massa da matéria seca do sistema radicular. As cultivares
Regina, Elisa e Verônica apresentaram maior massa de matéria seca da parte aérea $(8,09 ; 7,51$ e 7,20 g, respectivamente), mas apenas a cultivar Regina diferiu estatisticamente da cultivar Vera $(6,67 \mathrm{~g})$. Para o sistema radicular, no tratamento sem $P$. aphanidermatum a cultivar Regina teve a maior massa da matéria seca, sendo seguida pela cultivar Elisa, que foi seguida pelas cultivares Vera e Verônica. Nos tratamentos inoculados a cultivar Regina também manteve a maior massa da matéria seca, diferindo das cultivares Vera e Verônica, porém não diferindo da cultivar Elisa, que não diferiu da cultivar Vera. As cultivares crespas não diferiram entre si (Tabela 3 ). Nos dois experimentos realizados, as plantas inoculadas com $P$. aphanidermatum apresentaram a massa da matéria seca da parte aérea $(6,08$ e $6,12 \mathrm{~g})$ e do sistema radicular $(0,66$ e $0,61 \mathrm{~g})$ significativamente menor do que as não inoculadas $(7,44 \mathrm{e}$ $8,67 \mathrm{~g}$ da parte aérea e 0,89 e $1,22 \mathrm{~g}$ do sistema radicular, respectivamente) (Tabela 3 ).

No terceiro e no quarto experimentos realizados in vivo, também houve interação entre os fatores para a severidade da podridão de raízes (Tabela 4). Todas as plantas inoculadas apresentaram valores de severidade significativamente maiores que as não inoculadas. Com relação à matéria seca da parte aérea e do sistema radicular, no terceiro experimento não houve interação entre os fatores (Tabela 5). As cultivares Verônica e Vera tiveram menor massa de matéria seca da parte aérea $(6,20$ e $6,50 \mathrm{~g}$, respectivamente) e do sistema radicular $(0,71$ e $0,77 \mathrm{~g}$, respectivamente). Apresentaram maior massa de matéria seca da parte aérea $(7,27$ e 7,21 g) e do sistema radicular $(1,00$ e 0,90 g) as plantas das cultivares Regina e Elisa, respectivamente (Tabela 5). Assim como nos experimentos anteriores, as plantas de alface inoculadas com $P$. aphanidermatum tiveram menor massa da matéria

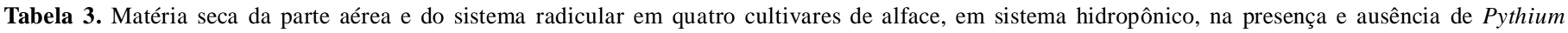

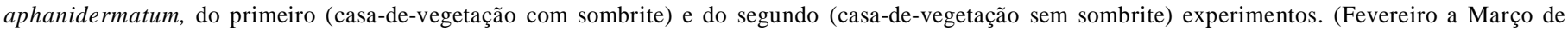
2006).

\begin{tabular}{|c|c|c|c|}
\hline \multirow[t]{2}{*}{ Fatores } & \multicolumn{2}{|c|}{$1^{\circ}$ Experimento ${ }^{1}$} & \multirow[t]{2}{*}{$2^{\circ}$ Experimento $^{2}$} \\
\hline & Matéria seca (g) & Matéria seca (g) & \\
\hline Cultivares & Parte aérea & Sistema radicular & Parte aérea \\
\hline Verônica (crespa) & $6,45 b^{3}$ & $0,66 \mathrm{c}^{3}$ & $7,20 a b^{3}$ \\
\hline Vera (crespa) & $6,12 b$ & $0,68 \mathrm{bc}$ & $6,67 \mathrm{~b}$ \\
\hline Elisa (lisa) & $7,17 \mathrm{a}$ & $0,77 \mathrm{~b}$ & $7,51 \mathrm{ab}$ \\
\hline Regina (lisa) & 7,31 a & $0,93 \mathrm{a}$ & 8,09 a \\
\hline \multicolumn{4}{|l|}{ P. aphanidermatum } \\
\hline Com & $6,08 \mathrm{~b}$ & $0,63 \mathrm{~b}$ & $6,12 b$ \\
\hline Sem & 7,44 a & 0,89 a & 8,67 a \\
\hline \multirow[t]{2}{*}{$\mathrm{CV}(\%)$} & 16,9 & 27,5 & 26,3 \\
\hline & \multicolumn{2}{|c|}{$\begin{array}{c}2^{\circ} \text { Experimento }{ }^{2} \\
\text { Matéria seca }(\mathrm{g}) \\
\text { Sistema radicular } \\
\text { Pythium aphanidermatum }\end{array}$} & \\
\hline Cultivares & Com & Sem & \\
\hline Verônica (crespa) & $0,43 \mathrm{c} \mathrm{B}^{3}$ & $0,92 \mathrm{c} \mathrm{A}^{3}$ & \\
\hline Vera (crespa) & $0,54 \mathrm{bc} \mathrm{B}$ & 0,99 с A & \\
\hline Elisa (lisa) & $0,69 \mathrm{ab} \mathrm{B}$ & $1,30 \mathrm{~b} \mathrm{~A}$ & \\
\hline Regina (lisa) & 0,80 a $\mathrm{B}$ & 1,69 a $\mathrm{A}$ & \\
\hline$\overline{\mathrm{CV}(\%)}$ & & & \\
\hline
\end{tabular}


Tabela 4. Severidade da podridão de raízes de quatro cultivares de alface, cultivadas em sistema hidropônico, na presença e ausência de Pythium aphanidermatum, do terceiro (casa-de-vegetação com sombrite) e do quarto (casa-de-vegetação sem sombrite) experimentos. (Março a Abril de 2006).

\begin{tabular}{|c|c|c|c|c|}
\hline & \multicolumn{2}{|c|}{$3^{\circ}$ Experimento ${ }^{1}$} & \multicolumn{2}{|c|}{$4^{\circ}$ Experimento ${ }^{2}$} \\
\hline \multirow[t]{2}{*}{ Cultivares } & \multicolumn{2}{|c|}{ Nota $(0-10)^{3}$} & \multicolumn{2}{|c|}{ Nota $(0-10)^{3}$} \\
\hline & \multicolumn{2}{|c|}{ Pythium aphanidermatum } & \multicolumn{2}{|c|}{ Pythium aphanidermatum } \\
\hline Verônica (crespa) & 7,04 a $\mathrm{A}$ & $0,13 \mathrm{c} \mathrm{B}^{4}$ & 7,08 a $\mathrm{A}$ & $0,21 \mathrm{~b} \mathrm{~B}$ \\
\hline Vera (crespa) & 6,67 a $A$ & $0,83 \mathrm{bc} \mathrm{B}$ & 8,12 a $\mathrm{A}$ & $0,13 \mathrm{~b} \mathrm{~B}$ \\
\hline $\mathrm{CV}(\%)$ & \multicolumn{2}{|c|}{19,64} & \multicolumn{2}{|c|}{24,72} \\
\hline
\end{tabular}

${ }^{1}$ Experimento 1 - casa-de-vegetação coberta com filme plástico transparente e com sombrite.

${ }^{2}$ Experimento 2 - casa-de-vegetação coberta com filme plástico transparente

${ }^{3}$ Severidade estimada pela escala de notas: $0=0 \%, 1=1-10 \%, 2=11-20 \%, 3=21-30 \%, 4=31-40 \%, 5=41-50 \%, 6=51-60 \%, 7=61-70 \%, 8=81-$ $90 \%$ e $10=91-100 \%$ de severidade da podridão de raízes (7).

${ }^{4}$ Médias seguidas por letras distintas diferem entre si (Tukey 5\%). Letras minúsculas comparam médias na vertical e maiúsculas na horizontal.

seca da parte aérea e do sistema radicular que as não inoculadas.

No quarto experimento, as plantas da cultivar Vera não inoculadas com $P$. aphanidermatum apresentaram a menor matéria seca da parte aérea $(7,63 \mathrm{~g})$, enquanto a cultivar Regina teve a maior massa de matéria seca da parte aérea $(9,33 \mathrm{~g})$, mas não diferiu estatisticamente das cultivares Elisa e Verônica (8,58 e 8,54 g, respectivamente) (Tabela 6). Não houve diferença entre as cultivares para esta variável quando as plantas foram inoculadas. Com relação à matéria seca do sistema radicular, a cultivar Regina apresentou o maior valor $(1,75 \mathrm{~g})$ e a cultivar Verônica o menor valor entre as plantas não inoculadas $(0,88 \mathrm{~g})$. Nos tratamentos inoculados, a cultivar Verônica apresentou menor massa de matéria seca do sistema radicular $(0,25 \mathrm{~g})$ que as demais.

Nos quatro experimentos realizados in vivo, $P$. aphanidermatum causou podridão de raízes e reduziu a massa de matéria seca da parte aérea e do sistema radicular de todas as cultivares inoculadas, que se comportaram como suscetíveis. A presença de $P$. aphanidermatum nas raízes inoculadas foi confirmada pelo plaqueamento da solução nutritiva e das raízes das plantas com sintomas de podridão radicular em meio de cultura V8. Pythium aphanidermatum é considerado um patógeno bastante agressivo em sistemas hidropônicos (13), podendo

Tabela 5. Matéria seca da parte aérea e do sistema radicular de quatro cultivares de alface hidropônica, na presença e ausência de Pythium aphanidermatum, do terceiro experimento (casa-de-vegetação com sombrite). (Março a Abril de 2006).

\begin{tabular}{lcc}
\hline & $\begin{array}{c}\text { Matéria seca da } \\
\text { parte aérea }(\mathrm{g})\end{array}$ & $\begin{array}{c}\text { Matéria seca do } \\
\text { sistema radicular }(\mathrm{g})\end{array}$ \\
\hline Cultivares & & \\
\hline Verônica (crespa) & $6,20 \mathrm{~b}^{1}$ & $0,71 \mathrm{~b}$ \\
Vera (crespa) & $6,50 \mathrm{~b}$ & $0,77 \mathrm{~b}$ \\
Elisa (lisa) & $7,21 \mathrm{a}$ & $0,90 \mathrm{ab}$ \\
Regina (lisa) & $7,27 \mathrm{a}$ & $1,00 \mathrm{a}$ \\
\hline P. aphanidermatum & & $0,71 \mathrm{~b}$ \\
\hline com & $6,10 \mathrm{~b}$ & $0,98 \mathrm{a}$ \\
sem & $7,48 \mathrm{a}$ & 42,28 \\
\hline CV $(\%)$ & 17,14 &
\end{tabular}

${ }^{1}$ Médias seguidas por letras distintas diferem entre si ao nível de significância de $5 \%$ Tukey.
Tabela 6. Matéria seca da parte aérea e do sistema radicular de quatro cultivares de alface, cultivadas em sistema hidropônico, na presença e ausência de Pythium aphanidermatum, do quarto experimento (casa-devegetação sem sombrite). (Março a Abril de 2006).

\begin{tabular}{|c|c|c|c|c|}
\hline \multirow{3}{*}{ Cultivares } & \multirow{2}{*}{\multicolumn{2}{|c|}{$\begin{array}{c}\text { Matéria seca da } \\
\text { parte aérea }(\mathrm{g})\end{array}$}} & \multirow{2}{*}{\multicolumn{2}{|c|}{$\begin{array}{c}\text { Matéria seca do } \\
\text { sistema radicular }(\mathrm{g}) \\
\text { Pythium } \\
\text { aphanidermatum }\end{array}$}} \\
\hline & & & & \\
\hline & Com & Sem & Com & Sem \\
\hline Verônica (crespa) & 5,80 a $^{1}$ & $8.54 \mathrm{ab} \mathrm{A}{ }^{1}$ & $0,25 \mathrm{~b} \mathrm{~B}^{1}$ & $0,88 \mathrm{c}^{1}$ \\
\hline Vera (crespa) & 5,50 a $\mathrm{B}$ & 7,63 с A & 0,63 a $\mathrm{B}$ & $1,13 \mathrm{bc} \mathrm{A}$ \\
\hline Elisa (lisa) & 6,46 a $B$ & $8,58 \mathrm{ab} \mathrm{A}$ & 0,79 a B & 1,33 b A \\
\hline Regina (lisa) & 6,79 а $B$ & 9,33 a $\mathrm{A}$ & 0,96 а $\mathrm{B}$ & 1,75 a $\mathrm{A}$ \\
\hline
\end{tabular}

${ }^{1}$ Médias seguidas por letras distintas diferem entre si ao nível de significância de 5\% Tukey. Letras minúsculas comparam médias na vertical e maiúsculas na horizontal.

se espalhar rapidamente e com facilidade no sistema (3). Esta espécie foi a única patogênica, quando comparada a $P$. irregular e P. sylvaticum, em cultivo de pepino em sistema hidropônico (13). Menzies et al. (12) observaram redução no peso seco da parte aérea e no número de frutos comercializáveis colhidos, e ainda no armazenamento em pós colheita de frutos de pepino produzidos em sistemas hidropônicos, inversamente proporcional à concentração do inóculo de $P$. aphanidermatum aplicada na solução nutritiva. Em plantas de pepino cultivadas em sistema hidropônico, $P$. aphanidermatum foi mais agressivo que Pythium do grupo $\mathrm{F}$, reduzindo o comprimento das raízes e afetando severamente o crescimento das plantas (28). Os autores desse estudo observaram que os zoósporos de $P$. aphanidermatum, quando aplicados na solução nutritiva, foram atraídos para o sistema radicular, especialmente as raízes mais finas, onde rapidamente encistaram.

Nas plantas não inoculadas, $P$. aphanidermatum não foi detectado nas raízes, apesar de ter sido observado um pequeno escurecimento de raízes, pois as notas diferirem de zero. Este escurecimento pode ser atribuído a outros fatores, como condições da solução nutritiva e temperatura da água.

As temperaturas que prevaleceram nas casas-de-vegetação foram 
elevadas (mínima $20,1^{\circ} \mathrm{C}$ e máxima $40{ }^{\circ} \mathrm{C}$ ), tanto no ambiente com sombrite como no sem sombrite, e provavelmente contribuíram para a infecção das plantas de alface com $P$. aphanidermatum, pois se observaram notas semelhantes de severidade da podridão de raízes nos dois ambientes. No terceiro e quarto experimentos as temperaturas foram mais amenas (mínima $18{ }^{\circ} \mathrm{C}$ e máxima $34^{\circ} \mathrm{C}$ ), entre 33 e $36{ }^{\circ} \mathrm{C}$ no ambiente sem sombrite e entre 32 e $35^{\circ} \mathrm{C}$ no ambiente com sombrite. Nos experimentos conduzidos por Mattos et al. (11) nos meses de janeiro a março em estufa na região de Campinas, foram observadas temperaturas médias de 28 a $31{ }^{\circ} \mathrm{C}$ durante o dia e de 23 a $24{ }^{\circ} \mathrm{C}$ durante a noite no interior de canaletas. A temperatura que prevaleceu nos ambientes protegidos e provavelmente nas canaletas deve ter sido adequada à infecção das plantas por $P$. aphanidermatum, sendo as temperaturas de 25 até $35{ }^{\circ} \mathrm{C}$ favoráveis ao patógeno segundo Liu et al. (9), Owen-Going et al. (16), Patekosky \& Pires-Zotarelli $(17,18)$, e Raftoyannis et al. (20) e desfavoráveis ao crescimento da cultura da alface, que cresce melhor entre 15 a $24{ }^{\circ} \mathrm{C}(8)$.

De maneira geral, as cultivares do tipo lisa, e especialmente a cultivar Regina, apresentaram maior massa do sistema radicular e da parte aérea nas plantas inoculadas e não inoculadas com $P$. aphanidermatum. Em outros estudos, também conduzidos em sistemas hidropônicos, esta cultivar teve menor massa da matéria seca da parte aérea ou massa igual à observada nas cultivares do tipo crespa, mas maior número de folhas por pé. Casaroli et al. (4) verificaram no período do outono, em cultivo hidropônico, menor massa de matéria seca da parte aérea e do sistema radicular nas cultivares Regina e Elisa, que nas cultivares Vera e Verônica, embora as duas primeiras tivessem maior número de folhas que as últimas. Em experimentos conduzidos no verão por Schmidt et al. (24), as cultivares Regina e Verônica tiveram massas de matéria seca semelhante. Entretanto, a cultivar Regina teve quase o dobro de folhas por planta que a cultivar Verônica. Ohse et al. (14) também não observaram diferença no crescimento das cultivares Regina e Verônica em sistema hidropônico em experimento conduzido no outono em Santa Maria, RS.

Nos experimentos realizados in vitro e in vivo foi observado que todas as cultivares de alface testadas, tanto as do tipo lisa quanto as do tipo crespa, foram suscetíveis a $P$. aphanidermatum (Tabelas 1 a 5). Embora no sistema hidropônico a cultivar Regina tenha se desenvolvido mais na presença do patógeno, não se pode concluir que seja mais resistente à podridão de raízes causada por $P$. aphanidermatum, pois também foi a que mais cresceu nos sistemas não infestados. Este maior crescimento pode ser devido ao maior número de folhas que esta cultivar produz quando cultivada em solução NFT, variável que não foi medida neste estudo, mas que foi avaliada em estudos comparativos anteriores (4, 24). As cultivares do tipo crespa, Vera e Verônica, foram mais afetadas pela podridão de raízes no primeiro e segundo experimentos e podem ser um pouco mais suscetíveis, pois tiveram menor peso seco em todos os experimentos, assim como observado por outros autores $(2,17)$.

A colocação do sombrite sobre a casa-de-vegetação não reduziu suficientemente a temperatura para que a severidade da podridão de raízes nas cultivares testadas diminuísse significativamente. Assim, esta medida pouco contribuiu para o manejo da doença no período mais quente do ano.

As cultivares do tipo lisa, bem como as do tipo mimosa, de acordo com Oliveira et al. (15), são as mais indicadas para integrar programas de cruzamento dirigidos, visando a produção de novas cultivares destinadas ao cultivo hidropônico, pois mostraram-se mais divergentes geneticamente, e também apresentaram boas qualidades agronômicas. Os resultados deste estudo, bem como os de Baptista et al. (2), que em experimentos in vitro verificou boa tolerância da cultivar Mimosa ao ataque de $P$. dissotocum, e de Patekosky et al (17) com $P$. aphanidermatum, sugerem que as cultivares Mimosa e Regina, sejam incluídas nestes programas de melhoramento. Também se sugere a avaliação da resistência dos materiais em desenvolvimento à podridão de raízes causada por espécies de Pythium, pois este é um fator limitante para o cultivo hidropônico na época mais quente do ano.

Os resultados deste estudo permitem concluir que, entre as quatro cultivares testadas, não foram encontradas cultivares resistentes à podridão de raízes causada por $P$. aphanidermatum. Estes materiais, portanto, não podem ser utilizados como medida exclusiva para o manejo da doença em sistemas hidropônicos. Medidas recomendadas para o manejo da doença, como a limpeza e a desinfestação das canaletas, a troca da solução nutritiva, bem como a introdução de agentes de biocontrole no sistema $(22,29)$, precisam ser mantidas. Entretanto, a cultivar Regina parece apresentar maior adaptabilidade a esses sistemas para o plantio no período de verão.

\section{REFERÊNCIAS BIBLIOGRÁFICAS}

1. Adams, P.B. Pythium aphanidermatum oospore germination as affected by time, temperature, and $\mathrm{pH}$. Phytopathology, St. Paul, v. 61, p.1149-1150, 1971

2. Baptista, F.R.; Pires-Zottarelli, C.L.A.; Teixeira, L.D.; Santos Júnior, N.A. Avaliação patogênica in vitro de Pythium middletonii Sparrow e Pythium dissotocum Drechsler em alface. Summa Phytopathologica, Botucatu, v.37, n.1, p.52-58, 2011.

3. Calvo-Bado, L.A.; Petch, G.; Parsons, N.R.; Morgan, J.A.W.; Pettitt, T.R.; Whipps, J.M. Microbial community responses associated with the development of oomycete plant pathogens on tomato roots in soilless growing systems. Journal of Applied Microbiology, Oxford, v.100, p.1194-1207, 2006.

4. Casaroli, D.; Fagan, E.B.; Santos, O.S.; Bonnecarrère, R.A.G.; Nogueira Filho, H. Desempenho de onze cultivares de alface em duas formas diferentes de canais de cultivo, no sistema hidropônico. Revista da Faculdade de Zootecnia, Veterinária e Agronomia, Uruguaiana, v.10, p.114-123, 2004.

5. Gold, S.E.; Stanghellini, M.E. Effects of temperature on Pythium root rot of spinach grown under hydroponic conditions. Phytopathology, St. Paul, v. 75, p.333-337, 1984.

6. Gualberto, R.; Oliveira, P. S. R.; Guimarães, A. M. Adaptabilidade e estabilidade fenotípica de cultivares de alface do grupo crespa em cultivo hidropônico. Horticultura Brasileira, Campinas, v. 27, n. 1, p. 7-11, 2009.

7. Khan, A.; Sutton, J.C.; Grodzinski, B. Effects of Pseudomonas chlororaphis on Pythium aphanidermatum and root rot in peppers grown in small-scale hydroponic troughs. Biocontrol Science and Technology, v.13, n.6, p.615-630, 2003.

8. Knott, J.E. Handbook for vegetable growers. 2. ed. New York: John Wiley, 1962. $245 \mathrm{p}$.

9. Liu, W.; Sutton, J.C.; Grodzinski, B.; Kloepper, J.W.; Reddy, M.S. Biological control of Pythium root rot of chrysanthemum in small-scale hydroponic units. Phytoparasitica, Rehovot, v.35, n. 2, p.159-178, 2007.

10. Lopes, M.C.; Freier, M.; Matte, J.D.; Gärtner, M.; Franzener, G.; Casimiro, E.L.N.; Sevignani, A. Acúmulo de nutrientes por cultivares de alface em cultivo hidropônico no inverno. Horticultura Brasileira, Brasília, v.21, n.2, p. 211-215, 2003.

11. Mattos, K.M.C.; Angelocci, L.R.; Furlani, P.R.; Nogueira, M.C.S. Temperatura do ar no interior do canal de cultivo e crescimento da alface em função do material de cobertura da mesa de cultivo hidropônico - NFT. Bragantia, Campinas, v.60, n.3, p.253260,2001

12. Menzies, J.G.; Ehret, D.L.; Stan, S. Effect of inoculums density of Pythium aphanidermatum on the growth and yield of cucumber 
plants grown in recirculating nutrient film culture. Canadian Journal of Plant Pathology, Ottawa, v.18, p.50-54, 1996.

13. Moulin, F.; Lemanceu, P.; Alabouvette, C. Pathogenicity of Pythium species on cucumber in peat-sand, rockwool and hydroponics. European Journal of Plant Pathology, Oxford, v.100, p.3-17, 1994.

14. Ohse, S.; Dourado-Neto, D.; Manfron, P. A.; Santos, O. S. Qualidade de cultivares de alface produzidos em hidroponia. Scientia Agricola, Piracicaba, v.58, n.1, p.161-185, 2001

15. Oliveira, A.C.B.; Sediyama, M.A.N.; Pedrosa, M.W.; Garcia, N.C.P.; Garcia, S.L.R. Divergência genética e descarte de variáveis em alface cultivada sob sistema hidropônico. Acta Scientiarum Agronomy, Maringá, v.26, no.2, p.211-217, 2004.

16. Owen-Going, N.; Sutton, J.C.; Grodzinski, B. Relationships of Pythium isolates and sweet pepper plants in single-plant units. Canadian Journal of Plant Pathology, Ottawa, v.25, p.155$167,2003$.

17. Patekoski, K.S.; Pires Zottarelli, C.L.A. Patogenicidade in vitro de Pythium aphanidermatum e Pythium dissotocum em variedades de alface (Lactuca sativa L.). Hoehnea, São Paulo, v. 36, n.1, p.161-172, 2009.

18. Patekoski, K.S.; Pires Zottarelli, C.L.A. Patogenicidade de Pythium aphanidermatum a alface cultivada em hidroponia e seu biocontrole com Trichoderma. Pesquisa Agropecuária Brasileira, Brasília, v.45, n.8, p.805-810, 2010.

19. Queiroga, R.C.F.; Bezerra Neto, F.; Negreiros, M.Z.; Oliveira, A.P.; Azevedo, C.M.S.B. Produção de alface em função de cultivares e tipos de tela de sombreamento nas condições de Mossoró. Horticultura Brasileira, Brasília, v.19, n.3, p.192-196, 2001.

20. Raftoyannis, Y.; Dick, M.W. Effects of inoculums density, plant age and temperature on disease severity caused by pythiaceous fungi on several plants. Phytoparasitica, Rehovot, v.30, n.1, p.67-76, 2002

21. Rahimian, M.K.; Banihashemi, Z. A method for obtaining zoospores of Pythium aphanidermatum and their use in determining cucurbit seedling resistance to dampping-off. Plant Disease, St.
Paul, v.63, n.8, p.658-661, 1979.

22. Rodrigues, L.R.F. Técnicas de cultivo hidropônico e de controle ambiental no manejo de pragas, doenças e nutrição vegetal em ambiente protegido. Jaboticabal: Unesp, 2002, $762 \mathrm{p}$.

23. Santos, O.; Bonnecarrère, R.; Schmidt, D.; Pilau, F.; Nogueira, H.; Manfron, P.; Menezes, N.; Casaroli, D.; Fagan, E. Recomendação de cultivares. Santa Maria: Centro de Ciências Rurais, 2000. 6 p. (Informe Técnico, 5 ).

24. Schmidt, D.; Santos, O.S.; Bonnecarrère, R.A.G; Mariani, O.A.; Manfron, P.A. Desempenho de soluções nutritivas e cultivares de alface em hidroponia. Horticultura Brasileira, Brasília, v.19, n.2, p. $122-126,2001$

25. Stanghellini, M.E.; Rasmussen, S.L. Hydroponics. A solution for zoosporic plant pathogens. Plant Disease, St. Paul, v.78, p.11291138, 1994

26. Sutton, J.C.; Sopher, C.R.; Owen-Going, T.N.; Liu, W.; Grodzinski, B.; Hall, J.C.; Benchimol, R.L. Etiology and epidemiology of Pythium root rot in hydroponic crops: current knowledge and perspectives. Summa Phytopathologica, Botucatu, v. 32, n.4, p.307-321, 2006.

27. Teixeira, L.D.; Zottarelli, C.L.A.; Kimati, H. Efeito da temperatura no crescimento micelial e patogenicidade de Pythium spp. que ocorre em alface hidropônica. Summa Phytopathologica, Botucatu, v.32, n.3, p.221-226, 2006.

28. Wulff, E.G.; Pham, A.T.H.; Chérif, M.; Rey, P.; Tirilly, Y.; Hockenhull, J. Inoculation of cucumber roots with zoospores of mycoparasitic and plant pathogenic Pythium species: differential zoospore accumulation, colonization ability and plant growth response. European Journal of Plant Pathology, Oxford, v. 104, p.69-76, 1998

29. Yañez, L.D.T. Identificação, patogenicidade e sensibilidade a produtos químicos in vitro de espécies de Pythium de cultura hidropônica de alface (Lactuca sativa L.). 2000. 74 f. Dissertação (Mestrado em Agronomia, área de concentração Fitopatologia): Escola Superior de Agricultura "Luiz de Queiroz", Universidade de São Paulo, Piracicaba. 